\title{
Spontaneous resolution of pneumopericardium in a preterm infant
}

\author{
Vishal Sidana, Rathnapratheep Rajasekaran, Jogender Kumar, ${ }^{\odot}$ Kanya Mukhopadhyay
}

Pediatrics, Post Graduate Institute of Medical Education and Research, Chandigarh, India

Correspondence to Dr Jogender Kumar, jogendrayadv@gmail.com, jogendrayadv@gmail.com

Accepted 1 May 2019

\section{DESCRIPTION}

A preterm neonate was born by vaginal delivery. $\mathrm{He}$ had difficult perinatal transition and required positive pressure ventilation for $60 \mathrm{~s}$. He had respiratory distress since birth for which nasal continuous positive airway pressure (CPAP) support was given. The chest $\mathrm{X}$-ray was suggestive of hyaline membrane disease (HMD), but due to financial constraints surfactant could not be given. The respiratory distress worsened, for which he needs to be intubated and ventilated. He required quite high ventilatory support (peak inspiratory pressure and peak end-expiratory pressure of $24 \mathrm{cmH}_{2} \mathrm{O}$ and $7 \mathrm{cmH}_{2} \mathrm{O}$, respectively). The baby was referred to us on manual intermittent positive pressure resuscitation on day 3 of life. On evaluation, he had bilateral equal air entry but muffled heart sounds. Therefore the possibility of pericardial effusion or pneumopericardium was considered and a chest X-ray was done. The chest X-ray shows a rim of air around the heart (figure 1) with almost white-out lungs, suggestive of isolated pneumopericardium. Since the baby was otherwise haemodynamically stable and was maintaining good saturation, we took an informed decision of 'not to drain' the pneumopericardium. Gradually the baby improved and was successfully extubated to nasal CPAP after 24 hours. Repeat chest X-ray while on CPAP support shows resolution of pneumopericardium with improved aeration of the lungs (figure 2 ). He was weaned off CPAP to room air by day 6 of life.

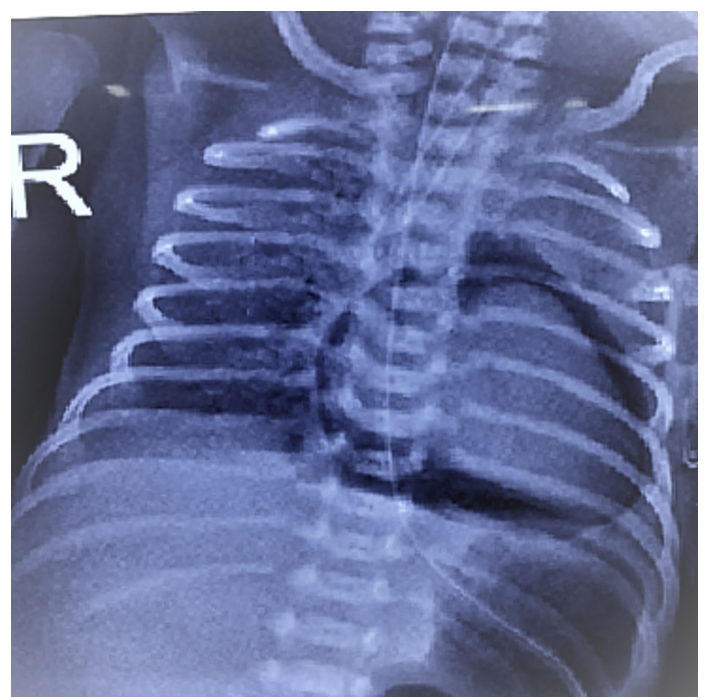

Figure 1 Chest X-ray showing the rim of air in the pericardial space and almost white-out lungs.

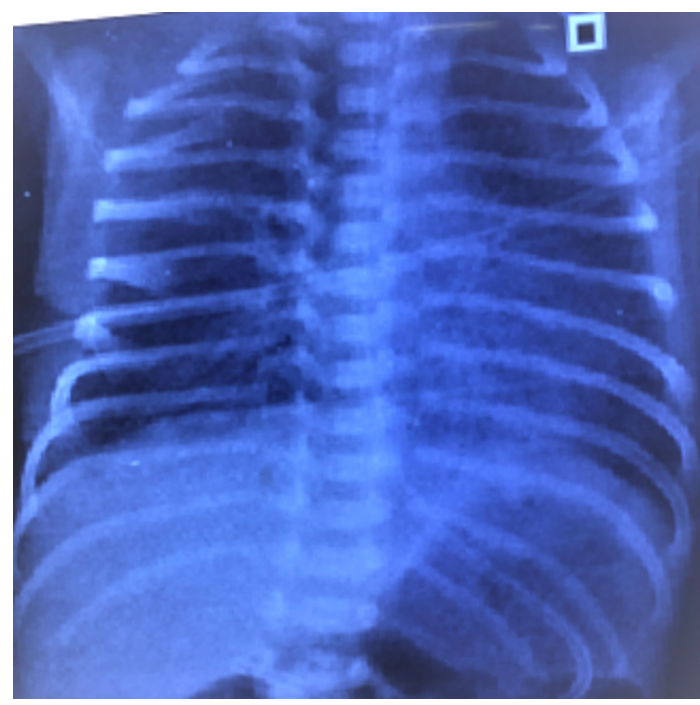

Figure 2 Chest X-ray showing resolution of pneumopericardium.

Various forms of air leaks such as pulmonary interstitial emphysema, pneumomediastinum, pneumothorax and pneumopericardium can occur in neonates. ${ }^{1}$ The postulated mechanism for air leaks is alveolar rupture and dissection of air along the connective tissue sheaths to the hilum. This air then enters the pericardium, where pericardial sac reflects over the pulmonary veins near the ostia of the pulmonary veins. ${ }^{2}$ This area of pericardial sac is identified as a potentially weak area because of lack of collagenous tissue. The risk factors for pneumopericardium described are surfactant deficiency, mechanical ventilation and positive pressure ventilation. Neonates with HMD are more prone to alveolar rupture, and exposure to mechanical ventilation appears to further contribute to the development of pneumopericardium. ${ }^{3}$ The spectrum of pneumopericardium can vary from asymptomatic to features such as respiratory distress, muffled and absent heart sounds, and severe haemodynamic instability. ${ }^{4}$ Pneumopericardium in neonates is managed conservatively, unless there is evidence of impending tamponade (ie, haemodynamic compromise). In the index case, the air leak was probably due to high ventilator pressures as well as poor compliance of the lungs. Antenatal corticosteroids and early CPAP are known to reduce the incidence and severity of HMD, but the findings cannot be generalised to lower income countries. ${ }^{5}$ Evidence suggests that early selective surfactant administration in HMD requiring assisted ventilation leads to an almost $40 \%$ reduction in the incidence of 
air-leak syndrome. ${ }^{6}$ In low-income to middle-income countries, where timely surfactant administration is not always feasible, the incidence of air-leak syndrome tends to be higher and contributes significantly to morbidity and mortality. Following extubation, resolution occurred rapidly probably due to the rapid decrease in mean positive airway pressure which promotes air leak to continue.

\section{Learning points}

Pneumopericardium, although a rare complication, should be suspected in neonates with hyaline membrane disease and on invasive mechanical ventilation.

- Muffled heart sound is an important clue of a collection in the pericardium, be it air or fluid.

- However impressive a pneumopericardium appears on X-ray, and if the neonate is haemodynamically stable it can be managed conservatively.
Contributors VS and RR managed the patient and drafted the manuscript. JK conceived the idea, supervised patient management and corrected the manuscript. KM supervised and provided critical inputs in writing. All authors approved the final version of the manuscript.

Funding The authors have not declared a specific grant for this research from any funding agency in the public, commercial or not-for-profit sectors.

Competing interests None declared.

Patient consent for publication Parental/guardian consent obtained.

Provenance and peer review Not commissioned; externally peer reviewed.

\section{REFERENCES}

1 Jeng MJ, Lee YS, Tsao PC, et al. Neonatal air leak syndrome and the role of highfrequency ventilation in its prevention. J Chin Med Assoc 2012;75:551-9.

2 Mansfield PB, Graham CB, Beckwith JB, et al. Pneumopericardium and pneumomediastinum in infants and children. J Pediatr Surg 1973:8:691-9.

3 Yeh TF, Vidyasagar D, Pildes RS. Neonatal pneumopericardium. Pediatrics 1974;54:129-33.

4 Roychoudhury S, Kaur S, Soraisham AS. Neonatal pneumopericardium in a nonventilated term infant: A case report and review of the literature. Case Rep Pediatr 2017;2017:1-4

5 Vogel JP, Oladapo OT, Pileggi-Castro C, et al. Antenatal corticosteroids for women at risk of imminent preterm birth in low-resource countries: the case for equipoise and the need for efficacy trials. BMJ Glob Health 2017;2:e000398.

6 Bahadue FL, Soll R. Early versus delayed selective surfactant treatment for neonata respiratory distress syndrome. Cochrane Database Syst Rev 2012;11:CD001456.

Copyright 2019 BMJ Publishing Group. All rights reserved. For permission to reuse any of this content visit https://www.bmj.com/company/products-services/rights-and-licensing/permissions/

BMJ Case Report Fellows may re-use this article for personal use and teaching without any further permission.

Become a Fellow of BMJ Case Reports today and you can:

- Submit as many cases as you like

- Enjoy fast sympathetic peer review and rapid publication of accepted articles

- Access all the published articles

- Re-use any of the published material for personal use and teaching without further permission

For information on Institutional Fellowships contact consortiasales@bmjgroup.com

Visit casereports.bmj.com for more articles like this and to become a Fellow 